\title{
In Vivo and in Vitro Evidence That PPAR $\gamma$ Ligands Are Antagonists of Leptin Signaling in Breast Cancer
}

\author{
Stefania Catalano, ${ }^{*}$ Loredana Mauro, ${ }^{\dagger}$ \\ Daniela Bonofiglio, ${ }^{*}$ Michele Pellegrino, ${ }^{\dagger}$ \\ Hongyan Qi, ${ }^{*}$ Pietro Rizza, ${ }^{\dagger}$ Donatella Vizza, ${ }^{*}$ \\ Gianluca Bossi, ${ }^{\ddagger}$ and Sebastiano Andò ${ }^{\dagger}$ \\ From the Departments of Pharmaco-Biology, ${ }^{*}$ and Cell-Biology, ${ }^{\dagger}$ \\ University of Calabria, Arcavacata; and the Regina Elena \\ Cancer Institute, ${ }^{\ddagger}$ Rome, Italy
}

Obesity is a major risk factor for the development and progression of breast cancer. Leptin, a cytokine mainly produced by adipocytes, plays a crucial role in mammary carcinogenesis and is elevated in hyperinsulinemia and insulin resistance. The antidiabetic thiazolidinediones inhibit leptin gene expression through ligand activation of the peroxisome proliferator-activated receptor- $\gamma(\operatorname{PPAR} \gamma)$ and exert antiproliferative and apoptotic effects on breast carcinoma. In this study, we investigated the ability of PPAR $\gamma$ ligands to counteract leptin stimulatory effects on breast cancer growth in either in vivo or in vitro models. The results show that activation of PPAR $\gamma$ prevented the development of leptin-induced MCF-7 tumor xenografts and inhibited the increased cell-cell aggregation and proliferation observed on leptin exposure. PPAR $\gamma$ ligands abrogated the leptin-induced up-regulation of leptin gene expression and its receptors in breast cancer. PPAR $\gamma$-mediated repression of leptin gene involved the recruitment of nuclear receptor corepressor protein and silencing mediator of retinoid and thyroid hormone receptors corepressors on the glucocorticoid responsive element site in the leptin gene expression regulatory region in the presence of glucocorticoid receptor and $\operatorname{PPAR} \gamma$. In addition, PPAR $\gamma$ ligands inhibited leptin signaling mediated by MAPK/STAT3/Akt phosphorylation and counteracted leptin stimulatory effect on estrogen signaling. These findings suggest that PPAR $\gamma$ ligands may have potential therapeutic benefits in the treatment of breast cancer. （Am J Pathol 2011, 179:1030-1040; DOI: 10.1016/j.ajpath.2011.04.026)

Several epidemiologic findings have established that obesity is a risk factor for human breast cancer. ${ }^{1}$ Indeed, increased body weight has been associated with shorter disease-free and overall survival in patients with breast cancer. $^{2}$

Leptin, a peptide hormone mainly secreted by adipocytes, is a pleiotropic molecule that regulates food intake, hematopoiesis, inflammation, immunity, cell differentiation, and proliferation. ${ }^{3}$ More recently, leptin has been found to be involved in neoplastic processes, particularly in mammary tumorigenesis. ${ }^{4,5}$ Specifically, in vitro and in vivo studies have shown that leptin stimulates tumor growth, cell survival, and transformation ${ }^{4,6,7}$ and amplifies estrogen signaling, contributing to hormonedependent breast cancer growth and progression. ${ }^{6,8}$

Peroxisome proliferator-activated receptor- $\gamma$ (PPAR $\gamma$ ) is a member of the nuclear receptor family of liganddependent transcription factors, which is best known for its differentiating effects on adipocytes and insulin-mediated metabolic functions. ${ }^{9}$ Activators of PPAR $\gamma$ include thiazolidinediones, a new class of antidiabetic drugs, such as rosiglitazone (BRL), that rather than reducing hyperglycemia and hyperinsulinemia in insulin-resistant states ${ }^{10}$ inhibit leptin expression and its signal transduction in different cell and animal models. ${ }^{1-14}$ PPAR $\gamma$ is also involved in cell-cycle control, inflammation, atherosclerosis, apoptosis, and carcinogenesis. ${ }^{15}$ The controversial role of PPAR $\gamma$ ligands in carcinogenesis has been reported, although the precise mechanisms responsible for differential effects (ie, proapoptotic versus proliferative) remain incompletely clarified. Some studies have demonstrated that activation of PPAR $\gamma$ increases tumor cell growth. ${ }^{16-18}$ However, most published studies imply the inhibitory effects of PPAR $\gamma$ ligands on the tumor growth of several carcinomas, including breast cancer. ${ }^{19,20}$ In the past few years, we have investigated different molecular mechanisms through which PPARy

Supported by Associazione Italiana Ricerca Cancro grants IG 1482, IG 8804, and MFAG 6180, ex 60\% Ministero Istruzione Università Ricerca.

Accepted for publication April 22, 2011.

S.C., L.M., and D.B. contributed equally to this work.

Supplemental material for this article can be found at $h$ ttp://ajp. amjpathol.org or at doi: 10.1016/j.ajpath.2011.04.026

Address reprint requests to Sebastiano Andò, Ph.D., Department CellBiology, University of Calabria, Arcavacata (CS) 87036, Italy. E-mail: sebastiano.ando@unical.it. 
may induce antiproliferative effects, cell-cycle arrest, and apoptosis in human MCF-7 breast cancer cells. ${ }^{21-23}$

In this study, we evaluated the ability of PPAR $\gamma$ ligands to counteract leptin stimulatory effects on breast cancer growth in either in vivo or in vitro models. These results have shown that PPAR $\gamma$ ligands reverse the enhanced expression of leptin gene (Lep; formerly $O b$ ) and its receptor (Lepr; formerly ObR), inhibiting the downstream signaling pathways induced by leptin. Transcriptional repression of $O b$ gene by PPAR $\gamma$ seems to be consequent to the recruitment of nuclear receptor corepressor protein (NCoR) and silencing mediator of retinoid and thyroid hormone receptors (SMRT) corepressors involving the participation of glucocorticoid receptor (GR).

\section{Materials and Methods}

\section{Plasmids}

The pHEGO plasmid, encoding the full length of estrogen receptor $\alpha(E R \alpha) c D N A$, and the reporter plasmid XETL, a construct containing an estrogen-responsive element, were gifts from Dr. Didier Picard (University of Geneva, Geneva, Switzerland). The plasmids containing the fulllength human leptin promoter or its deletions were gifts from Dr. Marc Reitman (NIH, Bethesda, MD).

\section{Site-Directed Mutagenesis}

The leptin promoter plasmid-bearing glucocorticoid responsive element-mutated site (p1775 GRE mut) was created by site-directed mutagenesis using a QuikChange kit (Stratagene, La Jolla, CA) and as template the human leptin promoter $\mathrm{p} 1775$. The mutagenic primers were 5 '-CCAGGCTGTAGTGCAATGGTCTtgCCTTGGCTCACTGCAACC-3' and 5'-GGTTGCAGTGAGCCAAGgcaAGACCATTGCACTACAGCCTGG-3'. Mutations are shown as italic and lower case letters. The constructed reporter vector was confirmed by DNA sequencing.

\section{Cell Cultures}

MCF-7, BT-20, and CHO cells were obtained from the American Type Culture Collection (Manassas, VA), were maintained in Dulbecco's modified Eagle's medium/ Ham's F-12 containing 5\% fetal bovine serum (Sigma, Milan, Italy), and were cultured in serum-free medium for at least 24 hours before treatments. All the media were supplemented with $1 \%$ L-glutamine and $1 \%$ penicillin/ streptomycin (Sigma).

\section{In Vivo Experiments}

Female 45-day-old athymic nude mice (nu/nu Swiss; Charles River Laboratories, Milan, Italy) were maintained in a sterile environment. At day 0 , estradiol pellets (1.7 mg per pellet, 90-day release; Innovative Research of America, Sarasota, FL) were subcutaneously implanted into the intrascapular region of the mice. The next day, MCF-7 cells $\left(5.0 \times 10^{6}\right.$ cells per mouse) were inoculated subcutaneously in $0.1 \mathrm{~mL}$ of Matrigel (BD Biosciences, Bedford, MA). Leptin treatment was performed as previously described. When the tumors reached $\sim 0.2 \mathrm{~cm}^{3}$ (ie, in 4 weeks), the animals received rosiglitazone (10 $\mathrm{mg} / \mathrm{kg} /$ day) in drinking tap water (Avandia, GlaxoSmith Kline, Middlesex, UK) for 8 weeks. MCF-7 xenograft tumor growth was monitored twice a week by caliper measurements, and tumor volumes (in cubic centimeters) were estimated by the following formula: TV $=a \times\left(b^{2}\right) / 2$, where $a$ and $b$ are tumor length and width, respectively, in centimeters. At week 12, blood samples were collected from the mice, and the animals were sacrificed following standard protocols; the tumors were dissected from the neighboring connective tissue, frozen in nitrogen, and stored at $-80^{\circ} \mathrm{C}$ for further analyses. After blood centrifugation, plasma was collected and kept at $-80^{\circ} \mathrm{C}$ for analyses. Plasma leptin concentration was measured using a commercially available mouse and rat leptin enzyme-linked immunosorbent assay kit (BioVendor, Heidelberg, Germany). All the procedures involving animals and their care were conducted in accordance with the institutional guidelines and regulations at the Laboratory of Molecular Oncogenesis, Regina Elena Cancer Institute, Rome, Italy.

\section{Histologic Analysis}

Tumors, livers, lungs, spleens, and kidneys were fixed in $4 \%$ formalin, sectioned at $5 \mu \mathrm{m}$, and stained with hematoxylin and eosin Y (Bio-Optica, Milan, Italy). The epithelial nature of the tumors was verified by immunostaining with mouse monoclonal antibody directed against human cytokeratin 18 (Santa Cruz Biotechnology, Milan, Italy), and nuclei were counterstained with hematoxylin. For negative controls, nonimmune serum replaced the primary antibody.

\section{Three-Dimensional Spheroid Culture and Cell Growth Assays}

For three-dimensional cultures, MCF-7 and BT-20 cells plated on 2\% agar-coated plates were treated with 1000 $\mathrm{ng} / \mathrm{mL}$ of leptin (Invitrogen, Carlsbad, CA) and/or 10 $\mu \mathrm{mol} / \mathrm{L}$ BRL (Alexis, San Diego, CA) and $10 \mu \mathrm{mol} / \mathrm{L} 15-$ deoxy- $\Delta 12,14$-prostaglandin J2 (PGJ2) (Sigma). After 48 hours, three-dimensional cultures were photographed using a phase-contrast microscope (Olympus, Milan, Italy). The extent of aggregation and cell numbers were evaluated as reported. ${ }^{7}$

\section{[3H]Thymidine Incorporation Assays}

MCF-7 and BT-20 cells were treated with leptin (1000 $\mathrm{ng} / \mathrm{mL})$ and/or BRL (10 $\mu \mathrm{mol} / \mathrm{L})$ and PGJ2 (10 $\mu \mathrm{mol} / \mathrm{L})$ for 48 hours and were pretreated for 2 hours with GW9662 (10 $\mu \mathrm{mol} / \mathrm{L}$; Sigma) or transfected with RNA interference (RNAi) for PPAR $\gamma$ where necessary. The assay was performed as previously reported. ${ }^{6}$ 


\section{RT-PCR Assays}

Total RNA was extracted using TRIzol reagent (Invitrogen). Reverse transcription was performed using a RETROscript kit (Ambion, Austin, TX). The cDNAs were amplified by PCR using the following primers: long isoform of $\mathrm{ObR}(\mathrm{ObRL})$ : 5'-CGAGAAACGTTTCAGCATCT-3' and 5'-CAAAAGCACACCACTCTCTC-3'; short isoform of ObR (ObRS): 5' GAAGGAGTCGGAAAACCAAAG-3' and 5'-CCACCATATGTTAACTCTCAG-3'; Ob: 5'-AGAGCCTTTGGATGACCAGAACAAGGTTCCCT-3' and 5'-TTACGAGAGAACTAACTGGAGAGCGACCTTT-3'; cathepsin D: 5'-AACAACAGGGTGGGCTTC-3' and 5'-ATGCACGAAACAGATCTGTGCT-3'; pS2 5'-TTCTATCCTAATACCATCGACG-3' and 5'-TTTGAGTAGTCAAAGTCAGAGC-3'; cyclin D1: 5'-TCTAAGATGAAGGAGACCATC-3' and 5'-GCGGTAGTAGGACAGGAAGTTGTT-3'; P450arom: 5'-CAAGGTTATTTTGATGCATGG-3' and 5'-TTCTAAGGTTTGCGCATGA-3'; and 36B4: 5'-CTCAACATCTCCCCCTTCTC-3' and 5'-CAAATCCCATATCCTCGT-3'.

The PCR was performed for 30 cycles for cathepsin D and cyclin D1; for 35 cycles for ObRL, ObRS, Ob, and P450arom; and for 15 cycles to amplify pS2 and 36B4 in the presence of $1 \mu \mathrm{L}$ of first-strand CDNA, $1 \mu \mathrm{mol} / \mathrm{L}$ each primer, $0.5 \mathrm{mmol} / \mathrm{L}$ dNTP, and TaqDNA polymerase (2 U per tube) (Promega Corp, Madison, WI) in a final volume of $25 \mu \mathrm{L}$.

\section{Western Blot Analysis and Immunoprecipitation Assays}

The phosphorylated forms of MAPK, STAT3, Akt, and GR S211 were identified by Western blot analysis in $50 \mu \mathrm{g}$ of whole lysate. The immunoblots were stripped and reprobed to determine total levels of MAPK, STAT3, Akt (Cell Signaling Technology, Milan, Italy), and GR (Santa Cruz Biotechnology). Immunoprecipitation was performed in $300 \mu \mathrm{g}$ of nuclear extracts in the presence of appropriate antibodies (Santa Cruz Biotechnology). Proteins were resolved on $8 \%$ to $10 \%$ SDS-polyacrylamide gels, transferred to a nitrocellulose membrane, and probed with specific antibodies (Novus Biologicals, Milan, Italy). The antigen-antibody complex was detected by incubation of the membrane at room temperature with a peroxidase-coupled goat anti-mouse or anti-rabbit IgG and revealed using the ECL system (Amersham, Buckinghamshire, UK).

\section{Transfection Assays}

MCF-7 cells were transfected using the FuGENE 6 reagent (Roche Diagnostics, Mannheim, Germany) with the mixture containing $0.5 \mu \mathrm{g}$ of luciferase-reporter plasmid and $5 \mathrm{ng}$ of $\mathrm{pRL}-\mathrm{CMV}$. CHO cells were transfected with XETL $(0.5 \mu \mathrm{g}$ per well) in the presence of HEGO $(0.2 \mu \mathrm{g}$ per well). After 24 hours of transfection, treatments were added and cells were incubated for 24 hours. The firefly luciferase values of each sample were normalized by Renilla luciferase activity, and the data are reported in relative light units.

\section{Electrophoretic Mobility Shift Assays}

Nuclear extracts were prepared from MCF-7 cells as previously described. ${ }^{24}$ The probe was generated by annealing single-stranded oligonucleotides labeled with $\left[\gamma^{32} \mathrm{P}\right]$ ATP and tyrosine polynucleotide kinase and then purified using Sephadex G-50 spin columns (Sigma). The DNA sequences used as probe or as cold competitors were as follows: GRE: 5'-ATGGTCTGATCTTGGCTCAC-3' and 5'-GTGAGCCAAGATCAGACCAT-3'; CRE: 5'-CACCGACGTCATTTGCAGTTCC-3' and 5' -CACCGACAGCTTTTGCAGTTCC-3'; and Sp1: 5'GAAAAACTCCGCCCTGGTAAAT-3' and 5'-ATTTACCAGGCGCGGAGTTTTTC-3'. The protein-binding reactions were performed as reported. ${ }^{7}$ The specificity of the binding was tested by adding to the mixture the reaction-specific antibodies anti-GR and anti-PPAR $\gamma$. The entire reaction mixture was electrophoresed through a $6 \%$ polyacrylamide gel in $0.25 x$ Tris-borate-EDTA for 3 hours at $150 \mathrm{~V}$.

\section{Chromatin Immunoprecipitation and Re-Chromatin Immunoprecipitation Assays}

MCF-7 cells were cross-linked with 1\% formaldehyde and sonicated. Supernatants were immunocleared with salmon sperm DNA/protein A agarose for 1 hour at $4^{\circ} \mathrm{C}$. The precleared chromatin was immunoprecipitated with specific anti-GR (E-20), PPAR $\gamma(\mathrm{H}-100)$, or anti-polymerase II (RNA-Poll H-224) antibodies (Santa Cruz Biotechnology) and were reimmunoprecipitated with anti-PPAR $\gamma$, anti-NCoR (NB120-2781), or anti-SMRT (NB300-732) antibodies (Novus Biologicals).

Normal mouse serum IgG was used as negative control. Pellets were washed as reported, eluted with elution buffer (1\% SDS, $0.1 \mathrm{~mol} / \mathrm{L} \mathrm{NaHCO}_{3}$ ), and digested with proteinase K. ${ }^{25}$ DNA was obtained by phenol/chloroform/ isoamyl alcohol extractions and were precipitated with ethanol; $5 \mu \mathrm{L}$ of each sample and input were used for real-time PCR with the primers flanking GRE sequence present in the leptin promoter region: 5'-GCCCAGGCTGTAGTGCAAT-3' and 5'-TAGCCAGGTGTGGTGG-3'. $P C R$ reactions were performed as reported. ${ }^{26}$

\section{Immunocytochemical Staining}

Cells were fixed in $4 \%$ paraformaldehyde, and hydrogen peroxide was used to inhibit endogenous peroxidase activity. Cells were incubated with 10\% normal horse serum to block nonspecific binding sites. Immunocytochemical staining was performed using specific primary antibodies (Santa Cruz Biotechnology). A biotinylated universal antibody made in horse was applied as secondary antibody (Vector Laboratories, Burlingame, CA). Amplification of avidin-biotin-horseradish peroxidase complex was performed, and 3,3'-diaminobenzidine tetrachloride dihydrate was used as a detection system. In 
control experiments (negative control), cells were processed, replacing the primary antibody with nonimmune rabbit IgG (Vector Laboratories).

\section{RNAi}

MCF-7 cells were transfected with 25-bp RNA duplex of validated RNAi-targeted human PPAR $\gamma$ mRNA sequence 5'-AGAAUAAUAAGGUGGAGAUGCAGGC-3' or with a stealth RNAi-negative control low GC (Invitrogen) to a final concentration of $100 \mathrm{nmol} / \mathrm{L}$ using Lipofectamine 2000 (Invitrogen), as recommended by the manufacturer. After 5 hours, the transfection medium was changed with serum-free medium to avoid Lipofectamine 2000 toxicity, and then cells were exposed to treatments.

\section{Statistical Analysis}

Each data point represents the mean \pm SE of at least three different experiments. Statistical analysis was performed using analysis of variance followed by NewmanKeuls testing to determine differences in means. Statistical comparisons for in vivo studies were made using the Wilcoxon-Mann-Whitney test. $P<0.05$ was considered statistically significant.

\section{Results}

\section{PPAR Ligands Reverse Leptin-Induced Tumor Cell Growth in Vivo and in Vitro}

First we explored the ability of BRL to inhibit leptin-induced breast tumor growth in vivo. To this aim, female nude mice, bearing into the intrascapular region of MCF-7 cell tumor xenografts, were treated with leptin and/or $B R L$. This administration was well tolerated because no change in body weight (see Supplemental Table S1 at http://ajp.amjpathol.org) or in food and water consumption was observed together with no evidence of reduced motor function. In addition, no significant difference in the mean weights or histologic features of the major organs (liver, lung, spleen, and kidney) after sacrifice was observed between vehicle-treated mice and those that received treatment, indicating a lack of toxic effects at the dose given.

Histologic examination of MCF-7 xenografts revealed that tumors were primarily composed of tumor epithelial cells (see Supplemental Figure S1 at http://ajp.amjpathol. org). Our results showed that leptin treatment induced tumor growth in mice, as we previously demonstrated, ${ }^{7}$ whereas a significant reduction in tumor volume was observed in the animal group receiving leptin plus BRL (Figure $1 \mathrm{~A})$. At week 12, tumor sizes were markedly smaller in

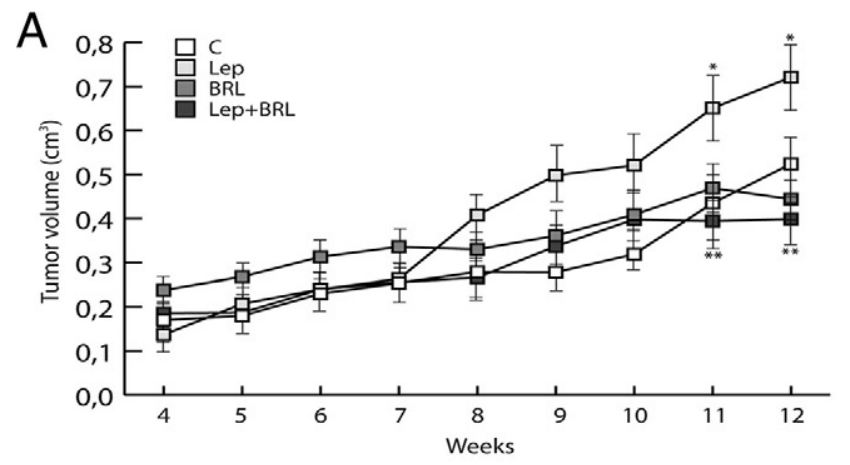

B

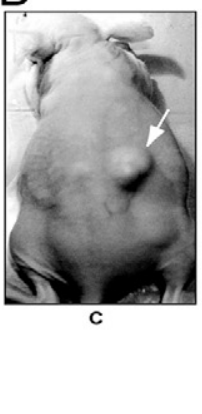

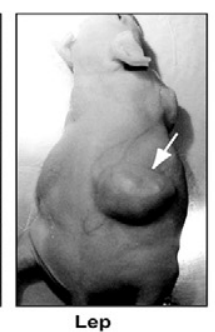

Lep

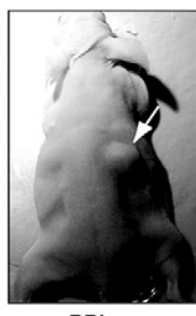

BRL

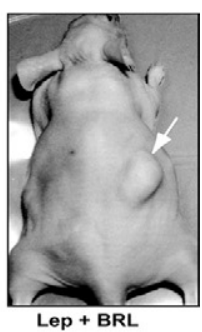

C
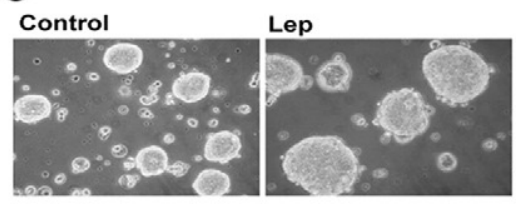

BRL

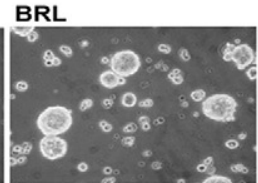

Lep+BRL

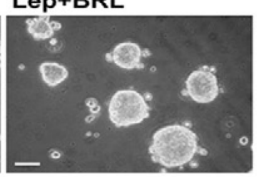

\begin{tabular}{|l|c|c|c|}
\cline { 2 - 4 } \multicolumn{1}{c|}{} & $\mathbf{2 5} \leq \mathbf{5 0} \boldsymbol{\mu \mathbf { m }}$ & $\mathbf{5 0} \leq \mathbf{1 0 0} \mu \mathbf{m}$ & $\geq \mathbf{1 0 0} \boldsymbol{\mu \mathbf { m }}$ \\
\hline Control & $27 \pm 1.1$ & $0.8 \pm 0.2$ & $0.0 \pm 0.0$ \\
\hline Lep & $6 \pm 0.6$ & $28 \pm 2.0$ & $82 \pm 2.2$ \\
\hline BRL & $32 \pm 1.6$ & $0.6 \pm 0.5$ & $0.0 \pm 0.0$ \\
\hline Lep+BRL & $39.5 \pm 0.8$ & $11 \pm 0.7$ & $9 \pm 1.1$ \\
\hline
\end{tabular}

D
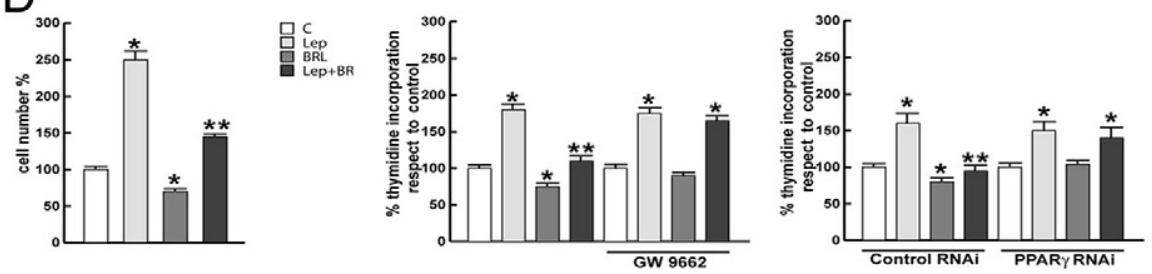

Figure 1. BRL reverses leptin-induced tumor cell growth. A: Tumor volume from MCF-7 xenografts implanted with estradiol pellets in female nude mice at weeks 4 and 12. The animals were treated with $230 \mu \mathrm{g} / \mathrm{kg} /$ day leptin (Lep) $(n=8), 10 \mathrm{mg} / \mathrm{kg} / \mathrm{day}$ BRL $(n=8)$, Lep and BRL $(n=8)$, or vehicle as control $(n=8) .{ }^{*} P<0.05$, leptin-treated group versus control group; ${ }^{* * *} P<0.05$, leptin plus BRL-treated group versus leptin-treated group. B: Representative images of experimental tumors at week 12 (arrows). C: MCF-7 three-dimensional cultures were untreated or treated as indicated for 48 hours (top). Scale bar $=50 \mu \mathrm{m}$. The extent of aggregation was scored by measuring the spheroid diameters. The values represent the sum of spheroids in 10 optical fields under $\times 10$ magnification (bottom). D: Cell numbers obtained from three-dimensional spheroids and proliferation determined by $\left[{ }^{3} \mathrm{H}\right]$ thymidine incorporation in MCF-7 cells transfected and treated as indicated for 48 hours. The results are mean \pm SE of three experiments. ${ }^{*} P<0.05$ versus untreated cells; ${ }_{* * *}^{*} P<0.05$ versus leptin. 
animals treated with leptin plus $B R L$ than with leptin alone (Figure 1B). Mean \pm SE plasma leptin levels measured at week 12 were significantly higher in leptin-treated mice $(2.05 \pm 0.087 \mathrm{ng} / \mathrm{mL}, P<0.01)$ than in vehicle-treated mice $(1.50 \pm 0.05 \mathrm{ng} / \mathrm{mL})$; in contrast, in BRL- $(1.13 \pm 0.06$ $\mathrm{ng} / \mathrm{mL}, P<0.01)$ and $\mathrm{BRL}+$ leptin- $(1.36 \pm 0.078 \mathrm{ng} / \mathrm{mL}$, $P<0.01)$ treated mice, leptin concentrations were decreased compared with those in the control and leptin groups.

We then performed three-dimensional MCF-7 cell cultures, which closely mimic some in vivo biologic features of tumors. ${ }^{27}$ We showed that BRL treatment (10 $\left.\mu \mathrm{mol} / \mathrm{L}\right)$ inhibited the enhanced cell-cell adhesion induced by leptin (1000 ng/mL) exposure as evidenced by the extent of aggregation scored by measuring the spheroid diameters (Figure 1C). In three-dimensional cultures, BRL decreased cell growth compared with untreated cells and reversed the enhanced leptin cell numbers. Moreover, the effects of leptin and/or BRL on cell proliferation were assessed by $\left[{ }^{3} \mathrm{H}\right]$ thymidine DNA incorporation assay. Leptin stimulated the growth of MCF-7 cells; this effect was completely inhibited by $\mathrm{BRL}$ treatment (Figure 1D). Similar results were also obtained using the natural PPAR $\gamma$ ligand PGJ2 (see Supplemental Figure S2 at $h t t p: / / a j p . a m j p a t h o l . o r g)$. The inhibitory effects exerted by PPAR $y$ ligands were no longer noticeable in the presence of the specific PPAR $\gamma$ antagonist GW9662 as well as PPAR $\gamma$ RNAi, demonstrating direct involvement of this nuclear receptor in antagonizing leptininduced tumor growth (Figure 1D).

In ER $\alpha$-negative breast cancer cells BT-20, BRL also reversed leptin-induced cell aggregation and cell pro- liferation (see Supplemental Figure S3 at http://ajp. amjpathol.org), suggesting that BRL effects are estrogen independent.

\section{BRL Represses Activation of Leptin Signal Transduction Pathways in MCF-7 Cells}

Leptin exerts its biologic function through binding to its receptors, which mediate a downstream signal by activating multiple signaling pathways. ${ }^{28,29}$ We examined the effects of $B R L$ on ObRs and its transduction pathways. Stimulation of MCF-7 cells with leptin resulted in an increase in $\mathrm{ObRL}$ and $\mathrm{ObRS}$, which was reversed by treatment with BRL (Figure 2A). Similar results were also obtained in MCF-7 xenografts (Figure 2B). In addition, as expected, leptin significantly induced phosphorylation of MAPK/STAT3/Akt in in vivo and in vitro models, whereas treatment with $B R L$ completely abrogated the leptin activation of these signaling pathways (Figure 2, C and D). All these data suggest that the inhibitory action of BRL on leptin-induced tumor growth, cell adhesion, and proliferation involves, at least in part, the ability of PPAR $\gamma$ ligand to modulate $\mathrm{ObR}$ expression and antagonize its signaling pathways.

\section{Modulation of Ob Expression and Its Transcriptional Activity by BRL}

To assess whether BRL can also affect Ob, we performed RT-PCR in MCF-7 cells. We showed in in vitro and in vivo
A

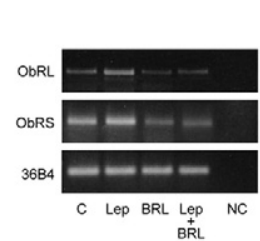

C
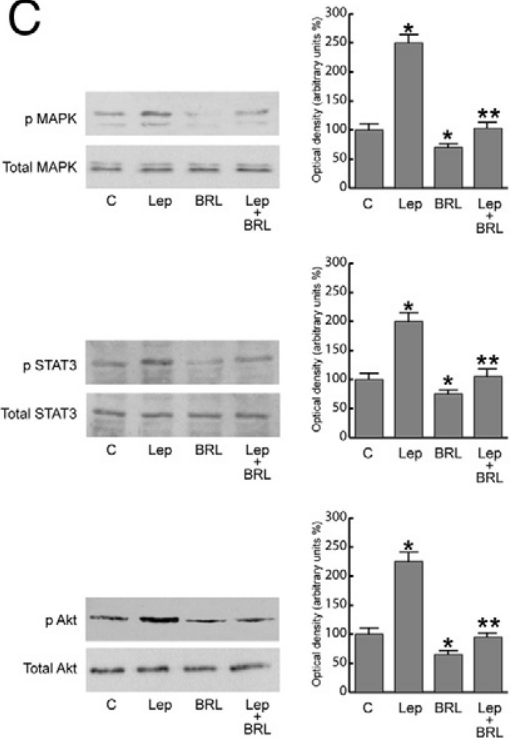

B
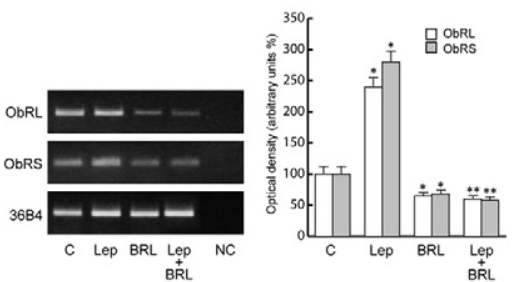

D
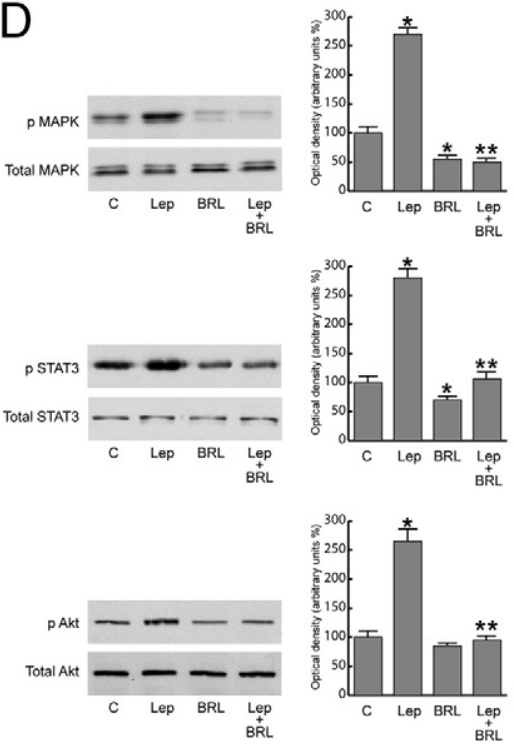

Figure 2. BRL represses leptin (Lep) signaling in MCF-7 cells and xenografts. RT-PCR of ObRL and ObRS mRNA from MCF-7 cells stimulated for 48 hours (A) and from xenografts (B). 36B4 mRNA levels were determined as control. NC indicates RNA sample without the addition of reverse transcriptase (negative control). Representative Western blot analysis on protein extracts from MCF-7 cells stimulated for 15 minutes (C) and xenografts excised from control and treated mice (D) showing MAPK/STAT3/Akt activation. The immunoblots were stripped and reprobed with total MAPK/STAT3/Akt as loading control. The results are mean \pm SE of three separate experiments in which the band intensities were evaluated in terms of optical density arbitrary units and expressed as the percentage of the control assumed to be $100 \%$. ${ }^{*} P<0.05$ versus untreated cells; ${ }^{* *} P<0.05$ versus leptin. 

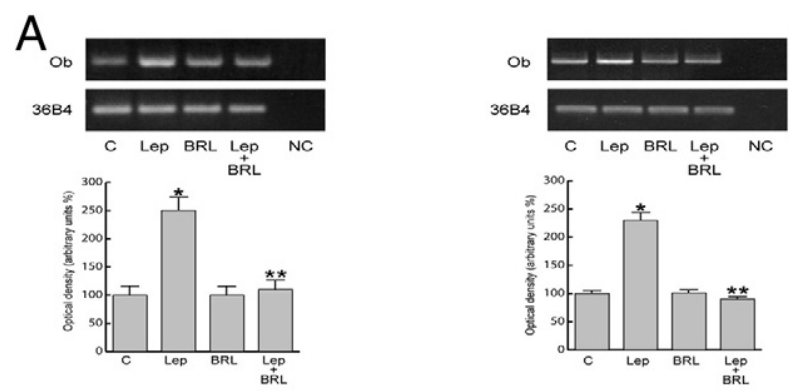

B
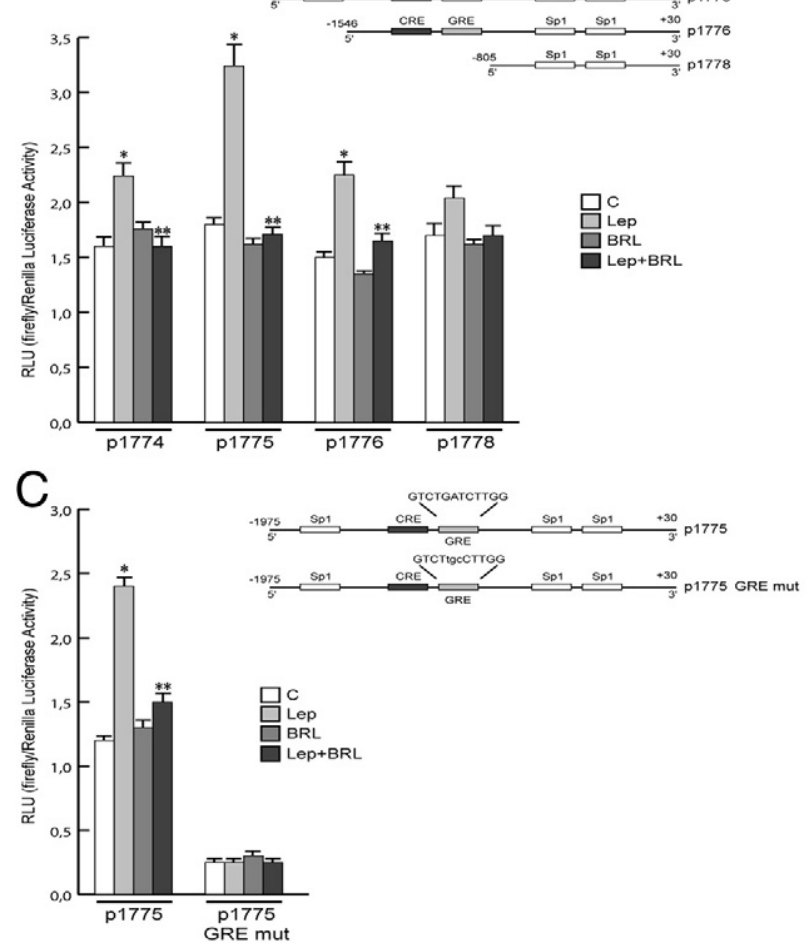

Figure 3. BRL negatively regulates leptin (Lep)-induced $\mathrm{Ob}$ expression and its transcriptional activity. A: RT-PCR of Ob was performed in MCF-7 cells stimulated for 48 hours (left panel) and in xenografts (right panel). 36B4 mRNA levels were determined as control. NC, negative control. MCF-7 cells were transiently transfected with luciferase plasmids containing the human leptin promoter (p1774) or its deletions (p1775, p1776, and p1778) (B) or p1775 mutated in the GRE site (p1775 GRE mut) (C). Schematic maps of the human leptin promoter constructs are included. Cells were untreated or treated with leptin $(1000 \mathrm{ng} / \mathrm{mL})$ and/or $10 \mu \mathrm{mol} / \mathrm{L}$ BRL for 24 hours. RLU indicates relative light units. The results are mean $\pm \mathrm{SE}$ of three separate experiments. ${ }^{*} P<0.05$ versus untreated cells; ${ }^{* *} P<0.05$ versus leptin.

models that leptin increased Ob mRNA, whereas BRL reversed this effect (Figure 3A). This latter result led us to ascertain whether PPAR $\gamma$ activation can modulate leptin transcriptional activity. To this aim, we transiently transfected MCF-7 cells with a plasmid containing leptin regulatory sequences p1774 $(-2922 /+30)$ and found that leptin induced luciferase activity, which was inhibited by treatment with BRL (Figure 3B). The Ob promoter contains multiple transcription factor binding motifs, including CRE and Sp1 sites and one GRE site (Figure 3B). To determine which cis-acting elements in the $\mathrm{Ob}$ promoter can mediate the previously mentioned effects, Ob promoter-deleted constructs $-1975 /+30$ (p1775), $-1546 /+30$ (p1776), and $-805 /+30$ (p1778) were tested. In transfection experiments performed using p1775 and p1776 constructs, the responsiveness to leptin was still observed, and BRL still inhibited the increase induced by leptin. In contrast, in the presence of the construct p1778, no up-regulatory effects were noticeable on leptin exposure (Figure 3B). Thus, we performed site-directed mutagenesis assays to evaluate which site was responsible for leptin-induced Ob promoter activation. We found that only the mutation of the GRE site was involved in mediating the stimulatory effect of leptin (Figure $3 \mathrm{C}$ ), addressing that the up-regulatory effect of leptin requires the GRE motif. To explore whether leptin affects the activity of GR, we tested its nuclear translocation and phosphorylation at S211. Leptin induced GR nuclear localization with a concomitant increase in S211 phosphorylated GR levels, which were significantly reduced by pretreatment with the MAPK inhibitor PD98059 and the JAK/STAT inhibitor AG490. In contrast, the PI3K inhibitor LY294002 did not affect GR phosphorylation status (Figure 4).

\section{PPAR $y$ Reverses Leptin-Induced Effects on $\mathrm{Ob}$ Promoter at the GRE Site through Corepressor Recruitment}

To provide insight into the molecular mechanism by which the GRE motif modulates Ob promoter activity, we performed electrophoretic mobility shift assay experi-
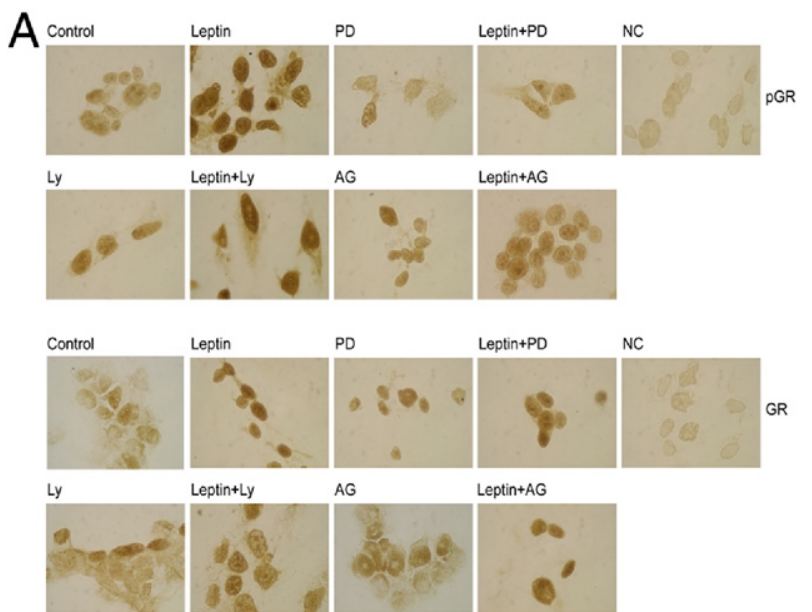

B

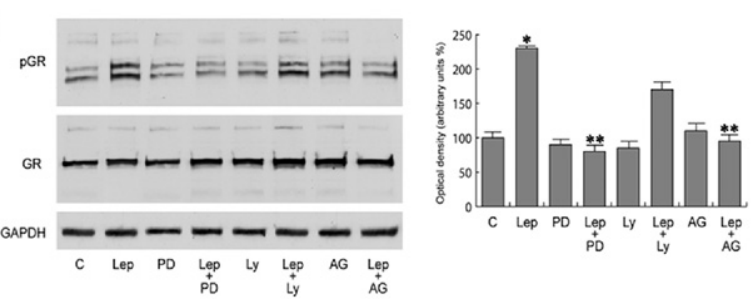

Figure 4. Leptin (Lep) induces nuclear translocation of GR and its phosphorylation (pGR). MCF-7 cells were untreated or treated with $1000 \mathrm{ng} / \mathrm{mL}$ of leptin for 15 minutes or pretreated with $10 \mu \mathrm{mol} / \mathrm{L}$ PD98059 (PD), AG490 (AG), or LY294002 (LY). A: Immunostaining of pGR and GR. No immunodetection was observed replacing the antibodies with horse serum [negative control (NC)]. B: Representative Western blotting for pGR on S211 and GR. Glyceraldehyde-3-phosphate dehydrogenase (GAPDH) was used as loading control. The results are mean \pm SE of three separate experiments for PGR in which the band intensities were evaluated in terms of optical density arbitrary units and expressed as the percentage of the control assumed to be $100 \%$. ${ }^{*} P<0.05$ versus untreated cells; ${ }^{* *} P<0.05$ versus leptin. 
ments using as a probe the GRE sequence present in the $\mathrm{Ob}$ regulatory region. We observed the formation of a complex in nuclear extracts from MCF-7 cells (Figure 5A, lane 1), which was abrogated by 100-fold molar excess of unlabeled probe (Figure 5A, lane 2), demonstrating the specificity of the DNA binding complex. This inhibition was no longer observed using a mutated oligodeoxyribonucleotide as competitor (Figure 5A, lane 3). Leptin and $B R L$ induced a slight increase in the specific band (Figure 5A, lanes 4 and 5), whereas an enhanced DNA binding complex was observed on combined treatments (Figure $5 \mathrm{~A}$, lane 6 ). The inclusion of anti-GR and anti-PPAR $\gamma$ antibodies in the reactions attenuated the specific bands, suggesting the presence of both proteins in the complex (Figure 5A, lanes 7 and 8). Note that the leptin-induced increase in the DNA binding complex was no longer noticeable when a synthetic oligodeoxyribonucleotide corresponding to the CRE or Sp1 motif was used as probe (data not shown).

The interaction of GR and PPAR $\gamma$ receptors with the Ob promoter was further elucidated by chromatin immunoprecipitation (ChIP) assays. Using anti-GR or antiPPAR $\gamma$ antibodies, protein-chromatin complexes were immunoprecipitated from MCF-7 cells treated for 1 hour with leptin and/or BRL. Real-time PCR was used to determine the recruitment of GR and PPAR $\gamma$ to the $\mathrm{Ob}$ region containing the GRE site. The results indicate that GR was constitutively bound to the Ob promoter in untreated cells and that this recruitment was increased on leptin or BRL exposure and to a higher extent after combined treatments. Immunoprecipitation with anti-PPAR $\gamma$ antibody showed enhanced recruitment of this nuclear receptor to the $\mathrm{Ob}$ promoter in the presence of $B R L$ and $B R L$ plus leptin treatments. Similar results were also obtained by GR/PPAR $\gamma$ Re-ChIP assay. We revealed after leptin treatment an enhanced association of RNA Pol II that was drastically reduced by leptin plus $B R L$ exposure (Figure 5B).

To assess whether the decrease in Ob promoter transcriptional activity might be caused by the cooperative interaction between GR/PPAR $\gamma$ and negative transcriptional regulators, we investigated the involvement of NCoR and SMRT, which interact with and function as negative coregulators of GR and PPAR $\gamma .{ }^{30-33}$ A coimmunoprecipitation assay was performed on nuclear protein fractions from MCF-7 cells treated with leptin and/or BRL. The formation of GR and PPAR $\gamma$ complex was clearly detected in all the conditions tested. Moreover, GR/NCoR and GR/SMRT complexes were slightly revealed in untreated cells, but this association was enhanced by combined treatments. No interaction of the orphan nuclear receptor DAX-1, a corepressor for GR, ${ }^{34}$ was observed under the same experimental conditions (Figure 5D). Similar results were obtained in MCF-7 cells immmunoprecipitated with anti-PPAR $\gamma$ antibody (Figure 5D).

Re-ChIP assays demonstrated increased NCoR and SMRT occupancy of the GRE-containing region of the $\mathrm{Ob}$ promoter after BRL exposure and particularly on combined treatments (Figure $5 \mathrm{C}$ ). In the presence of a MAPK inhibitor able to interfere with GR phosphorylation, the

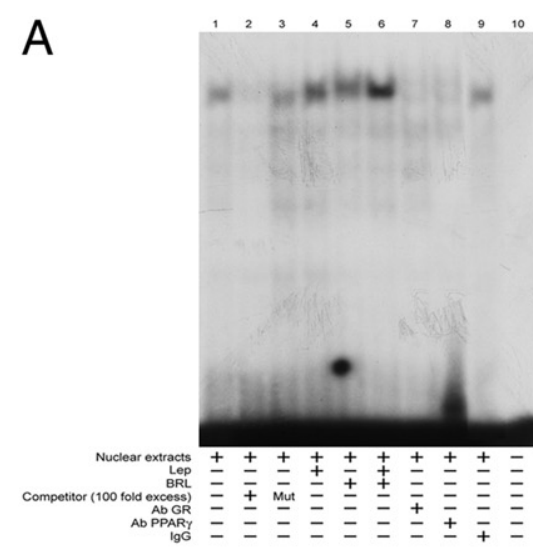

B
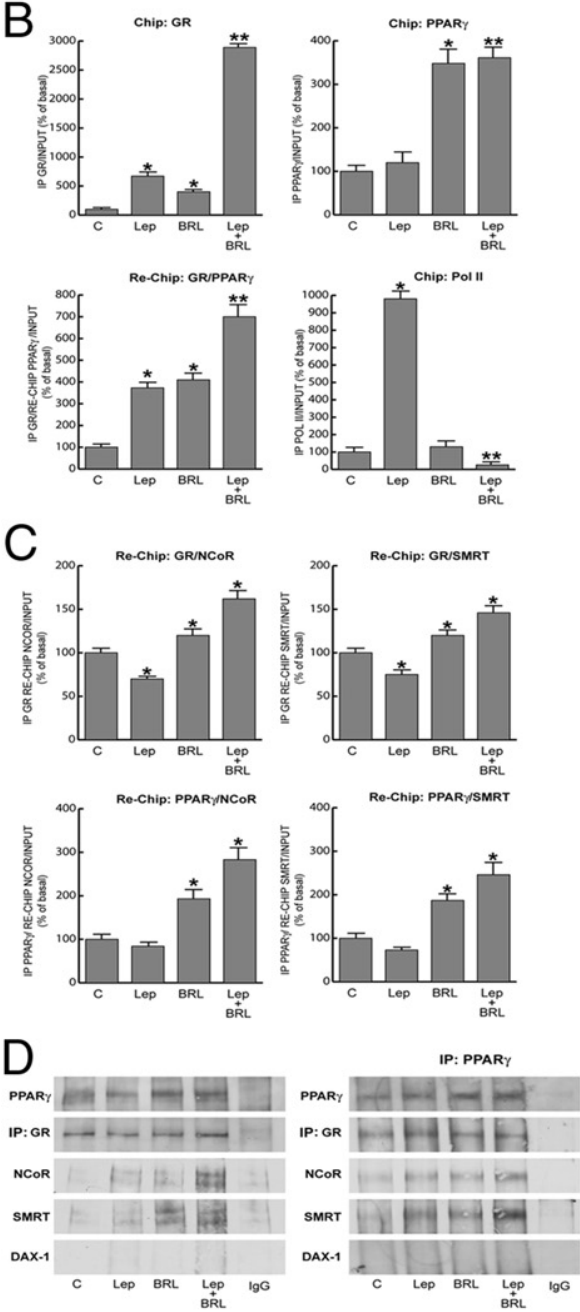

Figure 5. PPAR $\gamma$ binds and recruits corepressors to the GRE site in the $\mathrm{Ob}$ promoter. A: Nuclear extracts from MCF-7 cells were incubated with GRE probe (lane 1). A 100-fold molar excess of unlabeled (lane 2) and mutated (Mut) (lane 3) probe was added. MCF-7 nuclear extracts treated with $1000 \mathrm{ng} / \mathrm{mL}$ of leptin and/or $10 \mu \mathrm{mol} / \mathrm{L}$ BRL for 6 hours (lanes 4, 5, and 6). Anti-GR (lane 7), anti-PPAR $\gamma$ (lane 8) antibodies (Abs) or IgG (lane 9) were added to the mixture. Lane 10 shows probe alone. B: ChIP with the anti-GR, anti-PPAR $\gamma$, and anti-Pol II antibodies. ChIP with the anti-GR antibody was re-ChIP with anti-PPAR $\gamma$ antibody. C: ChIP with the anti-GR or anti-PPAR $\gamma$ antibodies was re-ChIP with either anti-NCoR or anti-SMRT antibodies. The leptin (Lep) promoter sequence including the GRE site was detected by real-time-PCR with specific primers (see Materials and Methods). The results are mean \pm SE of three separate experiments expressed as the percentage of control. ${ }^{*} P<0.05$ versus untreated cells; *** $P<0.05$ versus leptin. D: MCF-7 cells were treated with $1000 \mathrm{ng} / \mathrm{mL}$ of leptin and/or $10 \mu \mathrm{mol} / \mathrm{L}$ BRL for 48 hours. Immunoprecipitation was performed using anti-GR (left panel) or anti-PPAR $\gamma$ (right panel) antibodies and then blotted with anti-PPAR $\gamma, \mathrm{GR}, \mathrm{NCOR}, \mathrm{SMRT}$, or DAX-1 antibodies. 
recruitment of corepressors to the $\mathrm{Ob}$ promoter was markedly reduced (data not shown).

\section{BRL Abrogates Leptin-Activated Estrogen Signaling in MCF-7 Cells}

We previously demonstrated that leptin can transactivate $\mathrm{ER} \alpha$ and enhance aromatase gene expression in breast cancer cells. ${ }^{6,8}$ Thus, because PPAR $y$ ligands interfere with leptin signaling, we investigated the ability of $B R L$ to reverse the leptin effects on estrogen signaling.

In MCF-7 cells transiently transfected with XETL construct, we observed that BRL significantly inhibited EREdependent transactivation induced by leptin (Figure 6A), and this effect was reversed by pretreatment with GW9662 (data not shown). Similar results were reproduced in ER-negative $\mathrm{CHO}$ cells in which $\mathrm{ER} \alpha$ was ectopically expressed (Figure 6A).

These data correlated well with the ability of BRL to abrogate in in vivo and in vitro models the up-regulatory effects of leptin on mRNA expression levels of the classic estrogen genes cathepsin, pS2, and cyclin D1 (Figure $6 \mathrm{~B})$. Besides, in MCF-7 cell cultures and in xenografts, $B R L$ reversed the increase in aromatase expression induced by leptin (Figure 6C). These results indicate that treatment with BRL counteracting leptin action on estrogen signaling may contribute to reduce breast cancer cell growth and progression.

\section{Discussion}

For the first time, we demonstrate that activation of PPAR $\gamma$ reverses leptin-mediated promotion of breast tumor growth either in vivo in MCF-7 xenografts implanted in female nude mice or in vitro in MCF-7 three-dimensional and monolayer cultured breast cancer cells.

Elevated leptin levels strongly correlate with obesity, hyperinsulinemia, and insulin resistance, conditions found in most patients with diabetes mellitus. ${ }^{35}$ PPAR $\gamma$ ligands, thiazolidinediones, able to reduce hyperglycemia and hyperinsulinemia in insulin-resistant states, also down-regulate gene expression of pluripotent hormone leptin in vivo and in vitro. ${ }^{11,12}$ Besides, previous observations have reported that PPAR $\gamma$ agonists inhibited leptininduced proliferation in hepatic stellate cells by suppression of MAPK activation ${ }^{14}$ and abolished leptin-directed migration of endothelial cells through Akt. ${ }^{13}$ Thus, regulation and function of leptin and PPAR $\gamma$ are possibly interrelated and relevant in obese patients in whom metabolic changes are major contributors to the development of breast carcinoma.

The present results show that the PPAR $\gamma$ ligand BRL prevents the development of leptin-induced MCF-7 tumor xenografts in the presence of significantly lower plasma leptin levels and inhibits the increased cell-cell aggregation and proliferation observed on leptin exposure. The in vitro results were also reproduced in $\mathrm{ER} \alpha$-negative breast cancer cells BT20, addressing how the mechanism by which PPAR $\gamma$ activation affects breast tumor cell
A
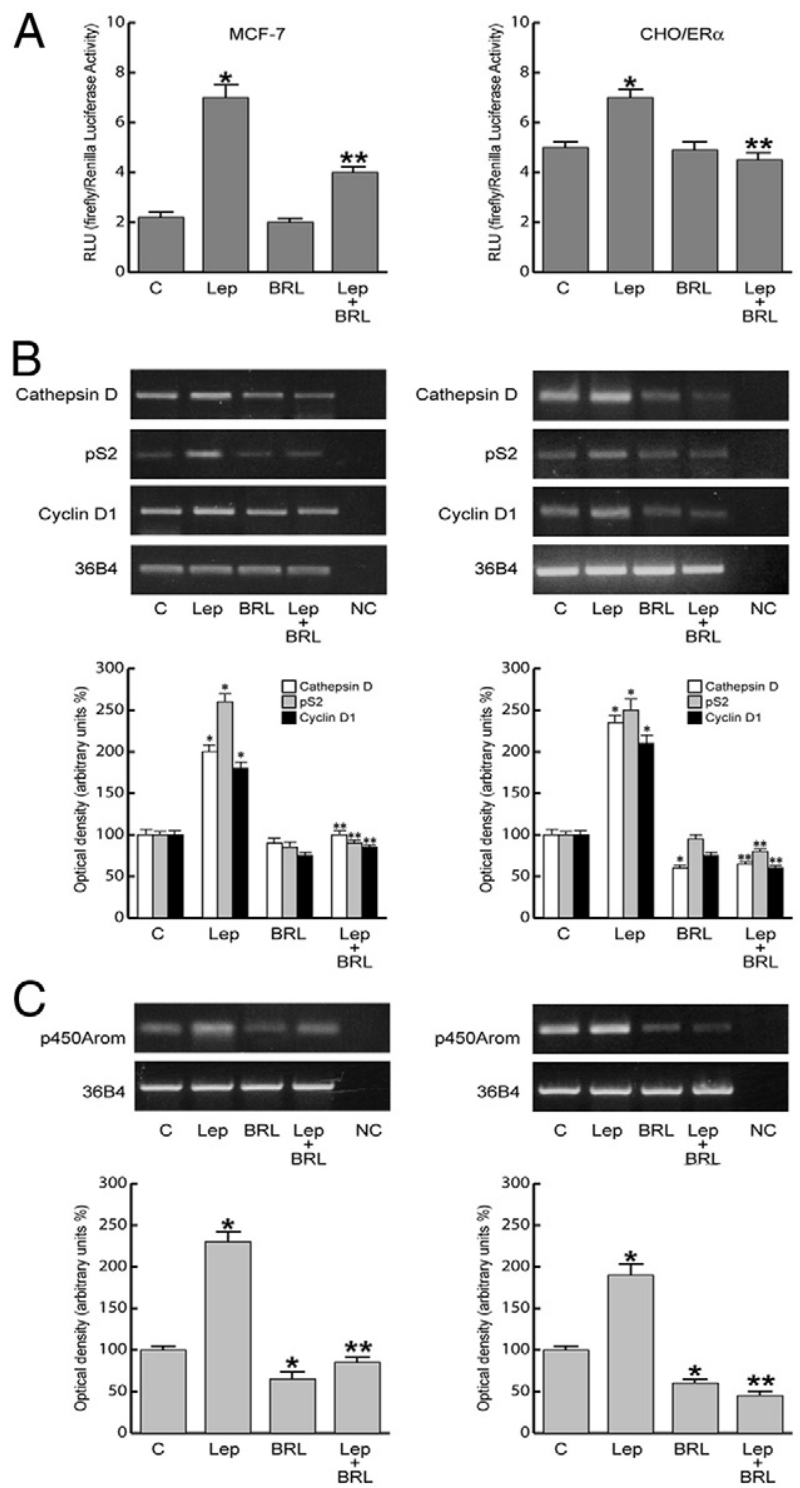

Figure 6. BRL antagonizes estrogen signaling induced by leptin (Lep). A: MCF-7 cells were transfected with XETL plasmid. CHO cells were cotransfected with XETL and HEGO plasmids $(\mathrm{CHO} / \mathrm{ER} \alpha)$. RLU, relative light unit. The results are mean $\pm \mathrm{SE}$ of three independent experiments performed in triplicate. ${ }^{*} P<0.05$ versus untreated cells; ${ }^{* *} P<0.05$ versus leptin. Cathepsin $\mathrm{D}, \mathrm{pS} 2$, and cyclin D1 (B) and aromatase (C) mRNA expression in MCF-7 cells treated for 48 hours as indicated (left panel) and in xenografts (right panel). 36B 4 mRNA levels were determined as control. NC indicates negative control. The results are mean \pm SE of three separate experiments in which the band intensities were evaluated in terms of optical density arbitrary units and expressed as the percentage of the control assumed to be $100 \%$. ${ }^{*} P<0.05$ versus untreated cells; ${ }^{* *} P<0.05$ versus leptin.

growth is not tightly related to estrogen dependency. Moreover BRL down-regulates the enhanced expression of ObRs induced by leptin and inhibits MAPK/Akt/STAT3 leptin downstream signaling pathways. These results are in agreement with data obtained in other cell models showing that PPAR $y$ ligands suppress ObR mRNA and its promoter activity and block leptin signaling. ${ }^{13,14,36}$

It emerges from recent studies that leptin and estrogen systems are involved in a functional cross talk. For example, leptin has been shown to directly transactivate $\mathrm{ER} \alpha^{8}$ and positively modulate aromatase activity. ${ }^{6}$ 
We demonstrated in MCF-7 cells that BRL, interfering with leptin signaling, could reverse the effects of leptin on estrogen signal specifically, counteracting ER $\alpha$ activation and its classic target genes in either in vitro or in vivo models.

Furthermore, the leptin-enhanced aromatase expression was completely abrogated by BRL treatment as we observed in xenografts and in monolayer cultures of MCF-7 cells, underlying the ability of this new class of oral antidiabetic drugs to inhibit local estrogen production, which represents an important factor of tumor microenvironment able to maintain tumor growth and progression.

Activated PPAR $\gamma$ is also known to inhibit the expression of $\mathrm{Ob}$ in adipose tissue. ${ }^{12,37}$ Herein, we demonstrated in MCF-7 cells the ability of BRL to reverse the leptin-induced $\mathrm{Ob}$ mRNA expression and its transcriptional activity, showing how PPAR $\gamma$ negatively interferes in the short autocrine loop maintained by leptin on $\mathrm{Ob}$ gene in breast cancer cells. The human $\mathrm{Ob}$ promoter contains multiple transcription regulatory elements, including several CRE, Sp1, and NFkB sites and one GRE site. ${ }^{38}$ Functional experiments using Ob promoter-deleted constructs and site-directed mutagenesis studies have shown that the up-regulatory effects induced by leptin on $\mathrm{Ob}$ promoter activity completely reversed by BRL occurred through the GRE site. These latter results fit well with the evidence that leptin induced GR translocation and phosphorylation at S211, which was inhibited by MAPK and JAK/STAT inhibitors. It was reported that the S211 phosphorylated GR strongly correlates with GR transcriptional activation; indeed, inhibition of this phosphorylation is associated with decreased nuclear retention of GR and inhibited gene transcription. ${ }^{39}$

The important role of GRE in regulating $\mathrm{Ob}$ promoter activity was also shown by electrophoretic mobility shift assays. We found in nuclear extracts from MCF-7 cells treated with leptin plus $B R L$ a strong increase in the GRE-DNA binding that was immunodepleted by anti-GR and anti-PPAR $\gamma$ antibodies, suggesting the presence of the two proteins in the complex.

The physiologic relevance of GRE in the $\mathrm{Ob}$ promoter in vivo is pointed out by ChIP analysis showing that the GR/PPAR $\gamma$ occupancy of the GRE-containing promoter region, induced by leptin plus $B R L$ treatment, is concomitant with a decrease in RNA Pol II recruitment and a reduction in $\mathrm{Ob}$ transcriptional activity.

It is known that members of the nuclear hormone receptor superfamily, including GR and PPAR $\gamma$, once activated, can interact physically and modulate target gene transcription. ${ }^{40,41}$ We have shown a strong association of PPAR $\gamma$ with GR in the nuclear fraction of untreated MCF-7 cells that was further potentiated by leptin plus BRL treatments.

PPAR $\gamma$ and GR can regulate transcription by several distinct mechanisms, and their functions, as shown for other corticosteroid receptors, seem to depend not only on ligand binding, which is known to regulate receptor conformation, but also on the context of the gene and associated promoter factors that contribute to create a gene-specific topography, achieving specific profiles of gene expression. ${ }^{42,43}$ Our proposed model for PPAR $\gamma$ - mediated repression of the $O b$ gene involves its interaction with GR and recruitment of the corepressors NCoR and SMRT, which share the same molecular architecture, interact with many of the same transcription factors, and assemble into similar corepressor complexes. ${ }^{44}$ NCoR and SMRT are recruited by PPAR $\gamma$ and GR to regulate the transcription of different genes. ${ }^{45,46}$ Overexpression of $\mathrm{NCoR}$ and SMRT represses PPAR $\gamma$-mediated gene transcription in certain cell types, ${ }^{47}$ and recently, increasing evidence suggests that these two corepressors modulate adipogenesis most likely via their ability to repress PPAR $\gamma$ action. ${ }^{48,49}$ The present results suggest that in MCF-7 cells on BRL and to a higher extent leptin plus BRL stimulation, NCoR and SMRT are recruited on the GRE site of the $\mathrm{Ob}$ promoter together with GR and PPAR $\gamma$.

A hypothetical model of the possible mechanism through which PPAR $\gamma$ activation may modulate leptin expression and function in reducing breast cancer growth is shown in Figure 7. Leptin, through JAK/STAT/MAPK activation, may phosphorylate GR and induce its transactivation, resulting in an increase in leptin promoter activity. This up-regulatory effect on $\mathrm{Ob}$ is counteracted by PPAR $y$ through the recruitment of corepressors NCoR and SMRT on the GRE site of the $\mathrm{Ob}$ regulatory region in the presence of GR and PPAR $\gamma$.

Moreover, activation of PPAR $\gamma$ also decreases ObRs, inhibits its transductional pathways, and negatively interferes with estrogen signaling through the down-regulation of aromatase gene expression and the inhibition of $\mathrm{ER} \alpha$ transactivation.

In conclusion, these data suggest that PPAR $\gamma$ ligands rather than ameliorate metabolic parameters may represent pharmacologic tools to be exploited in the novel therapeutic adjuvant strategies for breast cancer treatment.

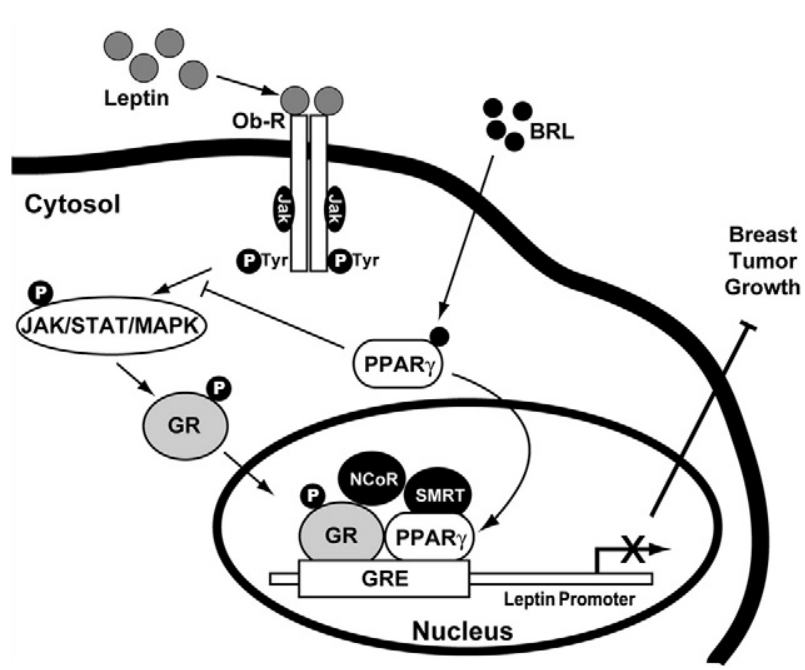

Figure 7. Molecular mechanism through which PPAR $\gamma$ counteracts leptin expression and function in breast cancer. Leptin, through JAK/STAT/MAPK activation, increases GR phosphorylation (pGR) and its nuclear translocation. pGR transactivates leptin promoter by binding to GRE motif. In the presence of BRL, PPAR $\gamma$ binds to GRE and, through the formation of GR/PPAR $\gamma$ complex, allows the recruitment of NCoR and SMRT corepressors, thus inhibiting $\mathrm{Ob}$ transcription and reducing breast tumor growth. 


\section{Acknowledgments}

We thank Dr. Vittoria Rago for her support in immunostaining assays and Dr. Pasquale Cicirelli for his technical assistance.

\section{References}

1. Calle EE, Kaaks R: Overweight, obesity and cancer: epidemiological evidence and proposed mechanisms. Nat Rev Cancer 2004, 4:579-591

2. Chlebowski RT, Aiello E, McTiernan A: Weight loss in breast cancer patient management. J Clin Oncol 2002, 20:1128-1143

3. Ahima RS, Flier JS: Leptin. Annu Rev Physiol 20006, 2:413-437

4. Garofalo C, Surmacz E: Leptin and cancer. J Cell Physiol 2006, 207:12-22

5. Vona-Davis L, Rose DP: Adipokines as endocrine, paracrine and autocrine factors in breast cancer risk and progression. Endocr Relat Cancer 2007, 14:189-206

6. Catalano S, Marsico S, Giordano C, Mauro L, Rizza P, Panno ML, Andò S: Leptin enhances, via AP-1, expression of aromatase in the MCF-7 cell line. J Biol Chem 2003, 278:28668-28676

7. Mauro L, Catalano S, Bossi G, Pellegrino M, Barone I, Morales S, Giordano C, Bartella V, Casaburi I, Andò S: Evidences that leptin up-regulates E-cadherin expression in breast cancer: effects on tumor growth and progression. Cancer Res 2007, 67:3412-3421

8. Catalano S, Mauro L, Marsico S, Giordano C, Rizza P, Rago V, Montanaro D, Maggiolini M, Panno ML, Andó S: Leptin induces, via ERK1/ERK2 signal, functional activation of estrogen receptor $\alpha$ in MCF-7 cells. J Biol Chem 2004, 279:19908-19915

9. Desvergne B, Wahli W: Peroxisome proliferator-activated receptors: nuclear control of metabolism. Endocr Rev 1999, 20:649-688

10. Quinn CE, Hamilton PK, Lockhart CJ, McVeigh GE: Thiazolidinediones: effects on insulin resistance and the cardiovascular system. $\mathrm{Br} \mathrm{J}$ Pharmacol 2008, 153:636-645

11. De Vos P, Lefebvre AM, Miller SG, Guerre-Millo M, Wong K, Saladin R, Hamann LG, Staels B, Briggs MR, Auwerx J: Thiazolidinediones repress ob gene expression in rodents via activation of peroxisome proliferator-activated receptor $\gamma$. J Clin Invest 1996, 98:1004-1009

12. Rieusset J, Auwerx J, Vidal H: Regulation of gene expression by activation of the peroxisome proliferator-activated receptor $\gamma$ with rosiglitazone (BRL 49653) in human adipocytes. Biochem Biophys Res Commun 1999, 265:265-271

13. Goetze S, Bungenstock A, Czupalla C, Eilers F, Stawowy P, Kintscher U, Spencer-Hänsch C, Graf K, Nürnberg B, Law RE, Fleck E, Gräfe M: Leptin induces endothelial cell migration through Akt, which is inhibited by PPAR $\gamma$-ligands. Hypertension 2002, 40:748-754

14. Lee JI, Paik YH, Lee KS, Lee JW, Kim YS, Jeong S, Kwon KS, Lee DH, Kim HG, Shin YW, Kim MA: A peroxisome-proliferator activated receptor- $\gamma$ ligand could regulate the expression of leptin receptor on human hepatic stellate cells. Histochem Cell Biol 2007, 127:495-502

15. Rocchi S, Auwerx J: Peroxisome proliferator-activated receptor- $\gamma$ : a versatile metabolic regulator. Ann Med 1999, 31:342-351

16. Lefebvre AM, Chen I, Desreumaux P, Najib J, Fruchart JC, Geboes K, Briggs M, Heyman R, Auwerx J: Activation of the peroxisome proliferators-activated receptor $\gamma$ promotes the development of colon tumors in C57BL/6J-APC Min/+ mice. Nat Med 1998, 4:1053-1057

17. Saez E, Tontonoz P, Nelson MC, Alvarez JG, Ming UT, Baird SM, Thomazy VA, Evans RM: Activators of the nuclear receptors PPAR $\gamma$ enhance colon polyp formation. Nat Med 1998, 4:1058-1061

18. Chinery R, Coffey RJ, Graves-Deal R, Kirkland SC, Sanchez SC, Zackert WE, Oates JA, Morrow JD: Prostaglandin J2 and 15-deoxy- $\Delta$ 12,14-prostaglandin $\mathrm{J} 2$ induce proliferation of cyclooxygenase-depleted colorectal cancer cells. Cancer Res 1999, 59:2739-2746

19. Elstner E, Müller C, Koshizuka K, Williamson EA, Park D, Asou H, Shintaku P, Said JW, Heber D, Koeffler HP: Ligands for peroxisome proliferator-activated receptor $\gamma$ and retinoic acid receptor inhibit growth and induce apoptosis of human breast cancer cells in vitro and in BNX mice. Proc Natl Acad Sci U S A 1998, 95:8806-8811

20. Grommes C, Landreth GE, Heneka MT: Antineoplastic effects of peroxisome proliferator-activated receptor $\gamma$ agonists. Lancet Oncol 2004, 5:419-429
21. Bonofiglio D, Gabriele S, Aquila S, Catalano S, Gentile M, Middea E, Giordano F, Andò S: Estrogen receptor $\alpha$ binds to peroxisome proliferator-activated receptor (PPAR) response element and negatively interferes with PPAR $\gamma$ signalling in breast cancer cells. Clin Cancer Res 2005, 11:6139-6147

22. Bonofiglio D, Aquila S, Catalano S, Gabriele S, Belmonte M, Middea E, Qi H, Morelli C, Gentile M, Maggiolini M, Andò S: Peroxisome proliferator-activated receptor $\gamma$ activates p53 gene promoter binding to the nuclear factor- $\kappa \mathrm{B}$ sequence in human MCF7 breast cancer cells. Mol Endocrinol 2006, 20:3083-3092

23. Bonofiglio D, Gabriele S, Aquila S, Qi H, Belmonte M, Catalano S, Andò S: Peroxisome proliferator-activated receptor $\gamma$ activates fas ligand gene promoter inducing apoptosis in human breast cancer cells. Breast Cancer Res Treat 2009, 113:423-434

24. Andrews NC, Faller DV: A rapid micropreparation technique for extraction of DNA-binding proteins from limiting numbers of mammalian cells. Nucleic Acids Res 1991, 19:2499

25. Morelli C, Garofalo C, Sisci D, del Rincon S, Cascio S, Tu X, Vecchione A, Sauter ER, Miller WH Jr, Surmacz E: Nuclear insulin receptor substrate 1 interacts with estrogen receptor $\alpha$ at ERE promoters. Oncogene 2004, 23:7517-7526

26. Sirianni R, Chimento A, Malivindi R, Mazzitelli I, Andò S, Pezzi V: Insulin-like growth factor-I, regulating aromatase expression through steroidogenic factor 1 , supports estrogen-dependent tumor Leydig cell proliferation. Cancer Res 2007, 67:8368-8377

27. Mauro L, Surmacz E: IGF-I receptor, cell-cell adhesion, tumor development and progression. J Mol Histol 2004, 35:247-253

28. Sweeney G: Leptin signalling. Cell Signal 2002, 14:655-663

29. Ahima RS, Osei SY: Leptin signaling. Physiol Behav 2004, 81:223-241

30. Cohen RN: Nuclear receptor corepressors and PPAR $\gamma$. Nucl Recept Signal 2006, 4:e003

31. Ricote M, Glass CK: PPARs and molecular mechanisms of transrepression. Biochim Biophys Acta 2007, 1771:926-935

32. van der Laan S, Meijer OC: Pharmacology of glucocorticoids: beyond receptors. Eur J Pharmacol 2008, 585:483-491

33. Ronacher K, Hadley K, Avenant C, Stubsrud E, Simons SS Jr, Louw A, Hapgood JP: Ligand-selective transactivation and transrepression via the glucocorticoid receptor: role of cofactor interaction. Mol Cell Endocrinol 2009, 299:219-231

34. Zhou J, Oakley RH, Cidlowski JA: DAX-1 (dosage-sensitive sex reversal-adrenal hypoplasia congenita critical region on the X-chromosome, gene 1) selectively inhibits transactivation but not transrepression mediated by the glucocorticoid receptor in a LXXLL-dependent manner. Mol Endocrinol 2008, 22:1521-1534

35. Zimmet P, Boyko EJ, Collier GR, de Courten M: Etiology of the metabolic syndrome: potential role of insulin resistance, leptin resistance, and other players. Ann N Y Acad Sci 1999, 892:25-44

36. Tang $Y$, Zheng $S$, Chen A: Curcumin eliminates leptin's effects on hepatic stellate cell activation via interrupting leptin signaling. Endocrinology 2009, 150:3011-3020

37. Kallen CB, Lazar MA: Antidiabetic thiazolidinediones inhibit leptin (ob) gene expression in 3T3-L1 adipocytes. Proc Natl Acad Sci U S A 1996, 93:5793-5796

38. Gong DW, Bi S, Pratley RE, Weintraub BD: Genomic structure and promoter analysis of the human obese gene. J Biol Chem 1996, 271:3971-3974

39. Chen W, Dang T, Blind RD, Wang Z, Cavasotto CN, Hittelman AB, Rogatsky I, Logan SK, Garabedian MJ: : Glucocorticoid receptor phosphorylation differentially affects target gene expression. Mol Endocrinol 2008, 22:1754-1766

40. Ialenti A, Grassia G, Di Meglio P, Maffia P, Di Rosa M, lanaro A: Mechanism of the anti-inflammatory effect of thiazolidinediones: relationship with the glucocorticoid pathway. Mol Pharmacol 2005, 67:1620-1628

41. Nie M, Corbett L, Knox AJ, Pang L: Differential regulation of chemokine expression by peroxisome proliferator-activated receptor $\gamma$ agonists: interactions with glucocorticoids and $\beta 2$-agonists. J Biol Chem 2005, 280:2550-2561

42. Hall JM, Couse JF, Korach KS: The multifaceted mechanisms of estradiol and estrogen receptor signaling. J Biol Chem 2001, 276: 36869-36872

43. Katzenellenbogen BS, Katzenellenbogen JA: Biomedicine: defining the "S" in SERMs. Science 2002, 295:2380-2381

44. Ghisletti S, Huang W, Jepsen K, Benner C, Hardiman G, Rosenfeld MG, Glass CK: Cooperative NCoR/SMRT interactions establish a 
corepressor-based strategy for integration of inflammatory and anti-inflammatory signaling pathways. Genes Dev 2009, 23:681-693

45. Gurnell M, Wentworth JM, Agostini M, Adams M, Collingwood TN, Provenzano C, Browne PO, Rajanayagam O, Burris TP, Schwabe JW, Lazar MA, Chatterjee VK: A dominant-negative peroxisome proliferatoractivated receptor $\gamma$ (PPAR $\gamma$ ) mutant is a constitutive repressor and inhibits PPAR $\gamma$-mediated adipogenesis. J Biol Chem 2000, 275:57545759

46. Wang Q, Blackford JA Jr, Song LN, Huang Y, Cho S, Simons SS Jr: Equilibrium interactions of corepressors and coactivators with agonist and antagonist complexes of glucocorticoid receptors. Mol Endocrinol 2004, 18:1376-1395
47. Krogsdam AM, Nielsen CA, Neve S, Holst D, Helledie T, Thomsen B, Bendixen C, Mandrup S, Kristiansen K: Nuclear receptor corepressor-dependent repression of peroxisome-proliferator-activated receptor delta-mediated transactivation. Biochem J 2002 , 363:157-165

48. Powell E, Kuhn P, Xu W: Nuclear receptor cofactors in PPAR $\gamma$-mediated adipogenesis and adipocyte energy metabolism. PPAR Res 2007, 2007:53843

49. Samarasinghe SP, Sutanto MM, Danos AM, Johnson DN, Brady MJ, Cohen RN: Altering PPAR $\gamma$ ligand selectivity impairs adipogenesis by thiazolidinediones but not hormonal inducers. Obesity (Silver Spring) 2009, 17:965-972 